Lepr Rev (1988) 59, 17-24

\title{
Ultrastructure of human foetal Schwann cells in tissue culture infected with Mycobacterium leprae
}

\author{
N M SAMUEL, ${ }^{*}$ C L CRAWFORD $\dagger \&$ J M GRANGE* \\ * Department of Microbiology, Cardiothoracic Institute, Brompton \\ Hospital, Fulham Road, London SW3 6HP, UK; † Department of \\ Anatomy, Charing Cross and Westminster Hospital, St Dunstan's \\ Road, London W6 8RP, UK
}

Accepted for publication 1 June 1987

Summary Human Schwann cells from foetal peripheral nerves were grown in tissue culture and infected with Mycobacterium leprae. After fixation for electron microscopy the ultrastructural features of infected Schwann cells were studied. The findings reproduce previous ultrastructural findings of adult human Schwann cells in tissue culture and clearly demonstrate that $M$. leprae infects cultured Schwann cells. Most of the $M$. leprae remained electron dense, suggesting retained viability, and did not appear to induce any toxic change in the Schwann cells.

\section{Introduction}

Inf ection of the Schwann cell by Mycobacterium leprae is considered to be an important factor in the pathogenesis of human leprosy. Ultrastructural observations have confirmed the presence of $M$. leprae in Schwann cells both in the human disease ${ }^{1,2}$ and in armadillos inf ected with the bacterium. ${ }^{3,4}$

In the last decade there has been considerable progress in tissue culture of various constitutents of peripheral nerves and it is now possible to selectively culture Schwann cells ${ }^{5,6}$ and ultrastructural observations have been made on such cells. ${ }^{7}$

Recently, cultured human foetal Schwann cells from peripheral nerves have been successfully infected with $M$. leprae. ${ }^{8}$ We now describe the ultrastructural features of these infected cells.

\section{Materials and methods}

TISSUE SAMPLES

Presumed healthy human foetuses of 8 to 20 weeks gestational age were obtained from the tissue bank at the Royal Marsden Hospital. The study of the foetal material was approved by the Ethical Committee of the Brompton Hospital. 


\section{CELL CULTURES}

\section{Primary cultures}

The peripheral nerves were dissected out. The connective tissue surrounding the nerve was removed under the dissecting microscope. The nerves were placed in calcium and magnesium f ree Dulbecco's modified Eagles medium (DMEM) which was obtained from the Zoology Department of University College, London. The peripheral nerves were placed in $35 \mathrm{~mm}$ diameter plastic Petri dishes (Nunc, Denmark) with $200 \mu \mathrm{l}$ of $0.4 \%$ collagenase and $200 \mu \mathrm{l}$ of $0.25 \%$ trypsin. The nerves were cut into small pieces and were then incubated in $10 \% \mathrm{CO}_{2}$ at $36^{\circ} \mathrm{C}$ for $30 \mathrm{~min}$. After this period the fluid was pipetted off under the dissecting microscope and replaced with $200 \mu \mathrm{l}$ of collagenase and $200 \mu \mathrm{l}$ of trypsin. The Petri dish was returned to the $\mathrm{CO}_{2}$ incubator for another $30 \mathrm{~min}$. This process was repeated a third time so that the total enzyme digestion was $1.5 \mathrm{hr}$. An equal volume of Eagles minimum essential medium plus 0.02M HEPES (MEM-H; $\mathrm{pH} 7.4$ ) and 15\% heat inactivated foetal calf serum (FCS) (Northumbria Biologicals Ltd) was added. The nerves were dissociated by two cycles of trituration through number 21 and 23 hypodermic needles (Becton Dickinson) and the suspension was transferred to a centrifuge tube and centrifuged at $180 \mathrm{~g}$ for $10 \mathrm{~min}$ at room temperature. The supernatant was removed and the pellet resuspended in DMEM plus $15 \%$ FCS and a count was made using haemocytometer. One to two $\mathrm{ml}$ of cellular suspension was placed in 50 $\mathrm{ml}$ flasks (Falcon) to be used for subcultures. After $24 \mathrm{hr}$ of incubation cytosine arabinoside $10^{-5} \mathrm{M}$ (Sigma) was added for $48 \mathrm{hr}$ to kill the dividing fibroblasts. After the removal of cytosine arabinoside by changing the medium the cells were maintained in DMEM $+15 \%$ FCS. The medium was changed twice weekly. The Schwann cells were identified by immunofluorescent staining with the specific neuroectodermal antigen $\mathrm{S}-100 .{ }^{8}$

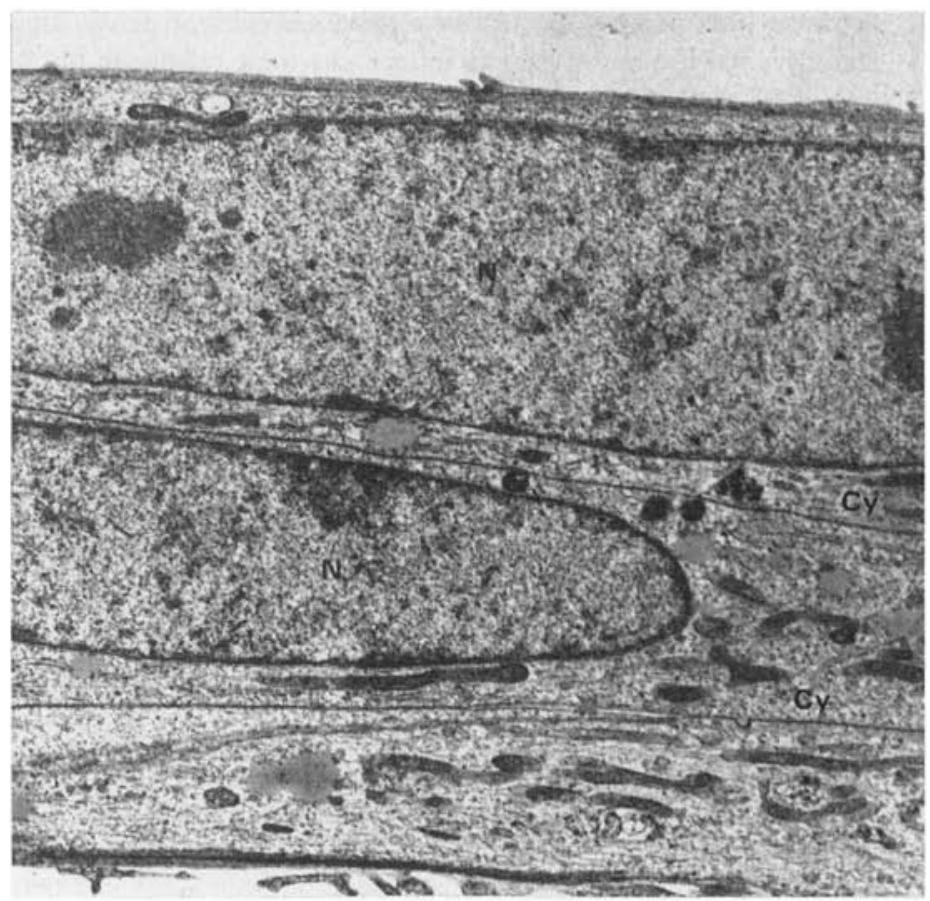

Figure 1. Low power picture of 3 Schwann cells lying adjacent to each other. Note the elongated nuclei $(\mathrm{N})$, prominent nucleoli and narrow cytoplasm $(\mathrm{Cy})$. (Original, $\times 12,000)$. 


\section{Secondary cultures}

Several days later the flasks were rinsed and then $0 \cdot 25 \%$ trypsin plus $0 \cdot 002 \%$ EDTA in calcium and magnesium free DMEM was added. The flasks were transferred to the incubator and left at $37^{\circ} \mathrm{C}$ for $30 \mathrm{~min}$. Cells were then harvested by centrifugation for $10 \mathrm{~min}$ at $260 \mathrm{~g}$, resuspended in the feeding medium and counted on a haemocytometer. The cell suspension was then transferred onto Thermanex (EMScope) cover slips which had previously been coated by immersion in D-poly-1lysine, $10 \mu \mathrm{g} / \mathrm{ml}$ (Sigma). Approximately 15-20,000 cells were seeded on each cover slip.

The cover slips were placed in 24 well tissue culture plates containing DMEM plus $15 \%$ FCS (Libro) and incubated in $10 \% \mathrm{CO}_{2}$ at $36^{\circ} \mathrm{C}$.

After 7 days growth, half the cultures were infected with fresh suspensions of armadillo-derived $M$. leprae containing $5 \times 10^{6} 6 \times 10^{6}$ organisms. After a further 3 days the cover slips were immersed in $2 \%$ glutaraldehyde in $0.1 \mathrm{M}$ cacodylate buffer $\mathrm{pH} 7.4 \mathrm{for} 1.5 \mathrm{hr}$ at room temperature, then for half an hour at $4^{\circ} \mathrm{C}$. They were then rinsed in $0 \cdot 1 \mathrm{M}$ cacodyulate buffer $\mathrm{pH} 7.4$ and immersed in $1 \%$ buffered osmium tetroxide for $45 \mathrm{~min}$. After another rinse in the buffer they were dehydrated in alcohols, immersed in propylene oxide and embedded in Araldite. After hardening, the cover slips were removed with forceps and thick, $1 \mu$, sections were cut from selected areas and stained with toluidine blue, and Schwann cells were identified. Thin sections were then cut with a Cambridge microtome, stained with uranyl acetate and lead citrate and viewed in an AE1 801 electron microscope.

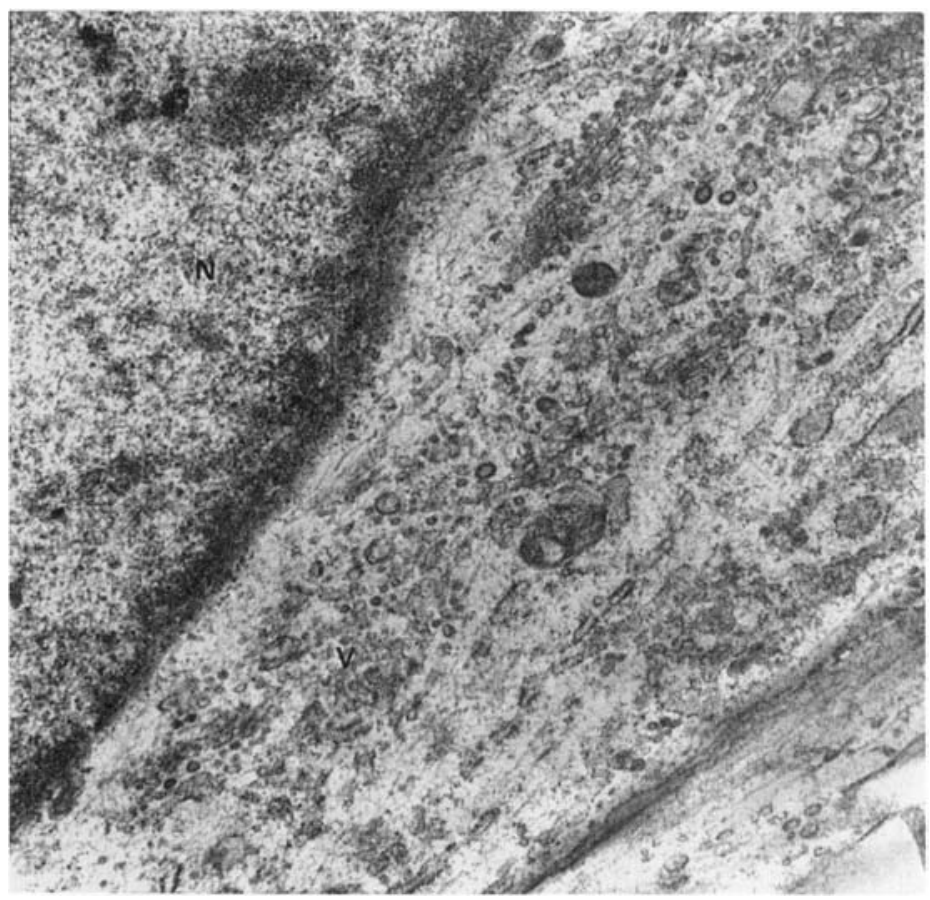

Figure 2. Perinuclear region of Schwann cell nucleus (N). Note extensive dense cored vesicles (V). Only occasional microtubules are present. (Original, $\times 23,500)$. 
$N$ M Samuel et al.

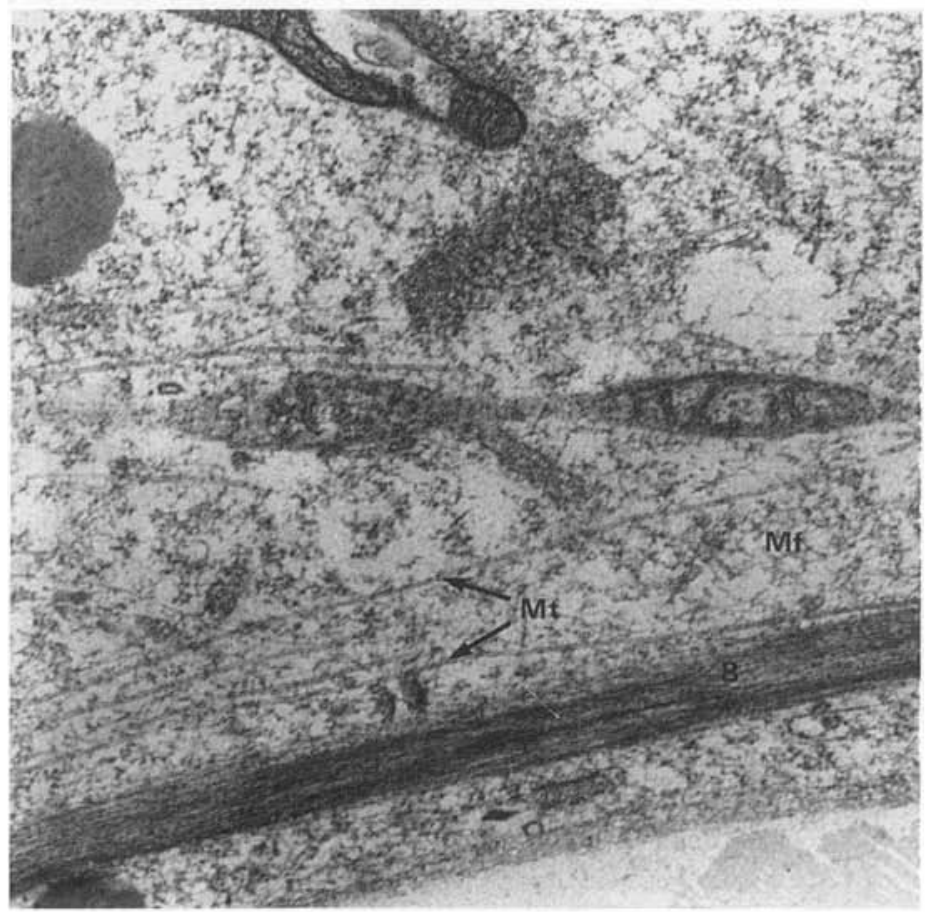

Figure 3. Polar cytoplasm of Schwann cell. Note the prominent microtubules (Mt) and how they are banded together to form a bundle (B). Microfilaments (Mf) are interspersed between the microtubules. (Original, $\times 42,000)$.

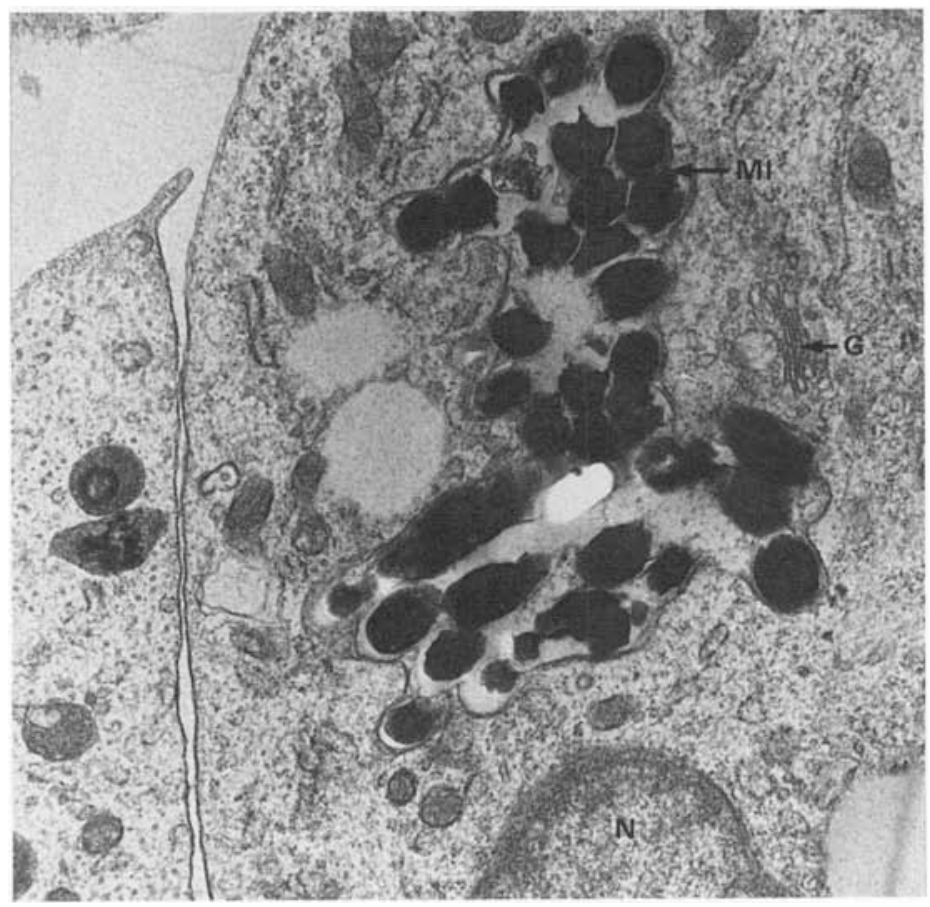

Figure 4. Numerous $M$. leprae in the perinuclear region enclosed in a common membrane within the Schwann cell cytoplasm. Nucleus $(\mathrm{N})$, M. leprae $(\mathrm{Ml})$, Golgi apparatus (G). (Original, ×33,600). 


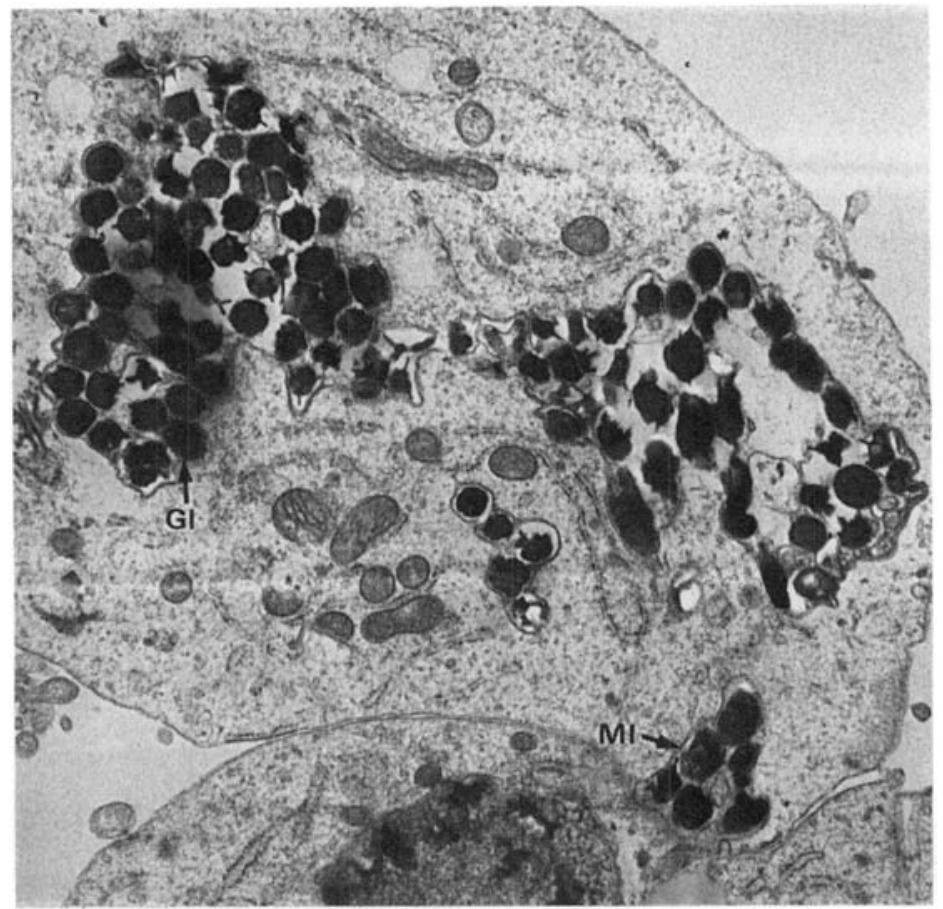

Figure 5. Heavily inf ected Schwann cell with 4 groups of $M$. leprae (Ml) enclosed in their own membrane. Globi (Gl). (Original, $\times 20,000)$.

\section{Results}

Schwann cells in cultures not infected with $M$. leprae had the following ultrastructural characteristics:

1 The cells were bipolar with an elongated nucleus and prominent nucleoli (Figure 1).

2 Golgi apparatus was present in the perinuclear region together with many free ribosomes and dense core vesicles (Figure 2).

3 Microtubules and microfilaments were sparse in the perinuclear region but were especially prominent in the processes (Figure 3).

4 Basement membranes were not present around the Schwann cells.

5 Fibroblasts were seen occasionally and were distinguished by their smaller size, the presence of extensive rough endoplasmic retinculum and the paucity of microtubules and microfilaments.

In cultures infected with $M$. leprae, the bacteria were found in abundance in Schwann cell cytoplasm (Figure 4), mostly in the perinuclear region. Some cells were heavily infected and globi were observed (Figure 5). Usually three or more bacteria were surrounded by an electron-dense common membrane (Figure 6) and none were seen lying free within the cytoplasm. The majority of $M$. leprae showed an even staining but occasional bacteria appeared fragmented (Figure 7). No fusion of phagosomes and lysosomes were observed.

In spite of the infection by $M$. leprae the appearance of the Schwann cells was similar to that in the control culture. That is, the cells were bipolar and the processes contained the characteristic microtubules and microfilaments while dense core vesicles, ribosomes and golgi apparatus were present in the perinuclear cytoplasm. 


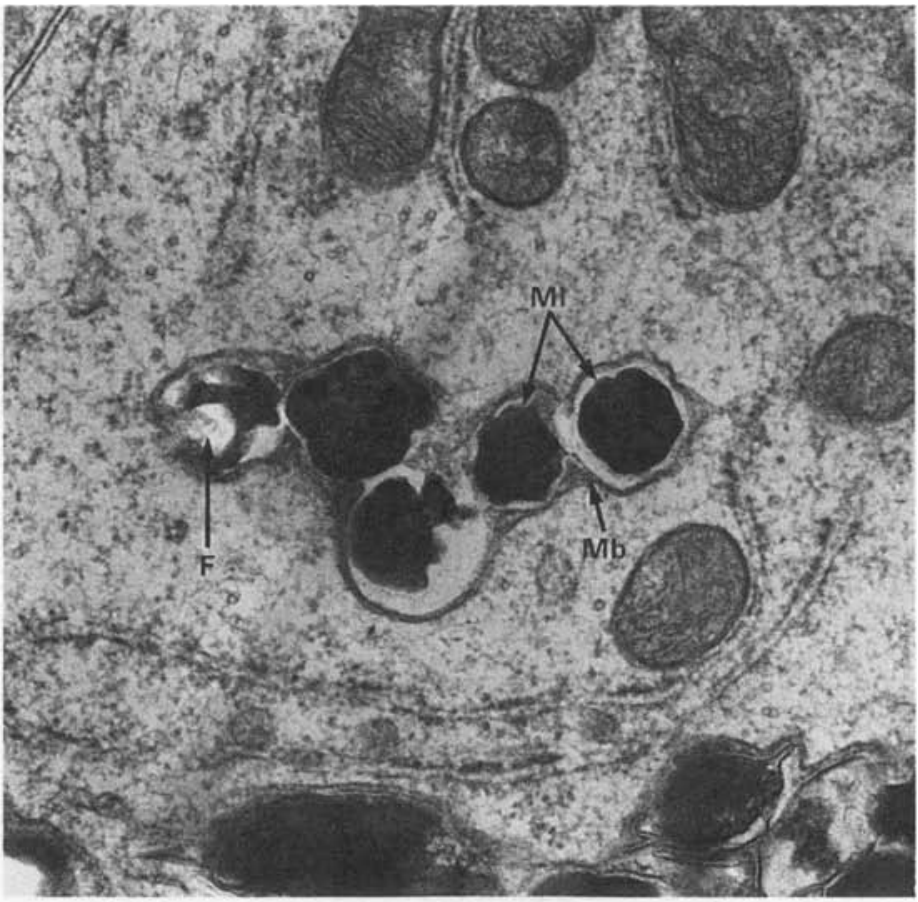

Figure 6. Five $M$. leprae ( $\mathrm{Ml}$ ) enclosed in a common membrane within the Schwann cell cytoplasm. Membrane $(\mathrm{Mb})$, Mitochondria $(\mathrm{M})$. One bacterium is fragmented $(\mathrm{F})$. (Original, $\times 72,000)$.

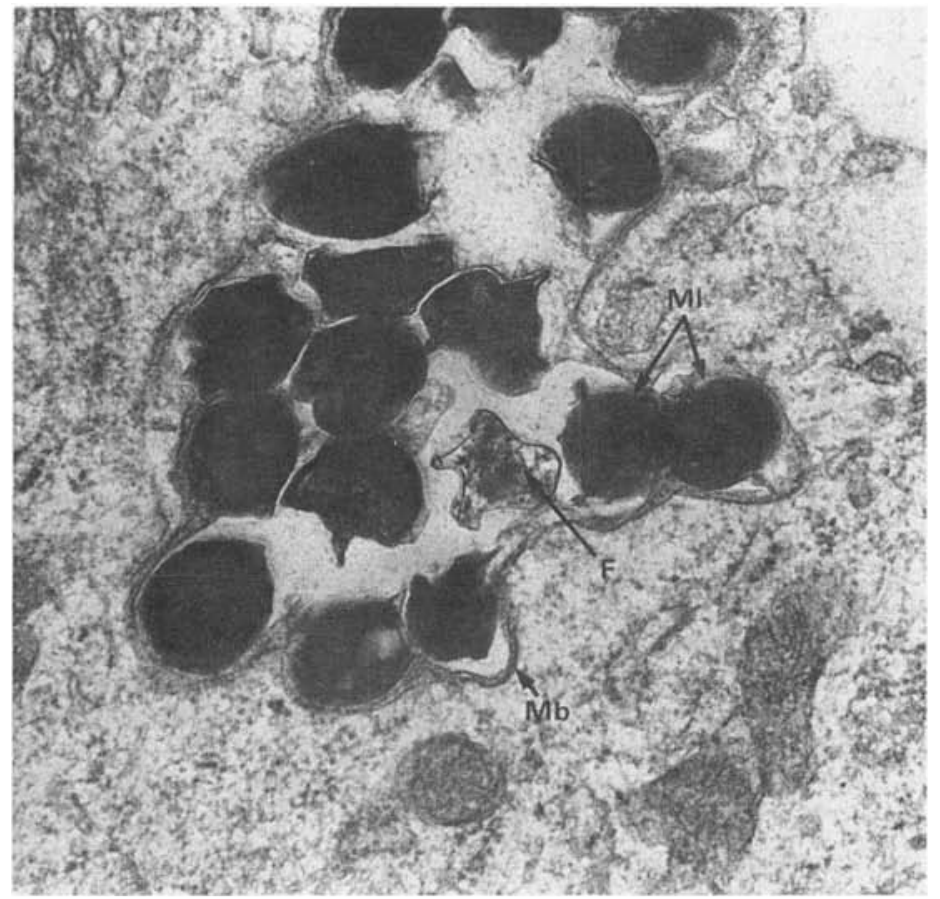

Figure 7. Group of $M$. leprae (Ml) enclosed in a common membrane (Mb) within Schwann cell cytoplasm (Cy). Most $M$. leprae shown are evenly stained but one bacterium is unevenly stained $(\mathrm{F})$ and is probably not viable. (Original, $\times 72,000)$. 


\section{Discussion}

The ultrastructural features of the Schwann cells observed here were very similar to those described by Askanas et $a l^{7}$ who grew the cells from nerve biopsies as explant cultures. Thus cultured Schwann cells of foetal peripheral nerves appear to possess the characteristic ultrastructure of their adult counterparts.

Schwann cells in tissue culture are not surrounded by a basement membrane so unfortunately this criterion cannot be used to distinguish them from fibroblasts. We have, however, already shown in a parallel study on the same cultures that cells of this morphology are S-100 positive ${ }^{8}$ thus confirming that they are Schwann cells. Also, the ultrastructural features already described, although not absolute, do permit a distinction as Askanas et al. have noted. ${ }^{7}$ The lack of basement membrane in cultured Schwann cells is thought to be due to the absence of neurons. Thus, when neurons and Schwann cells are cultured together, a basement membrane is formed. ${ }^{9}$

This study provided confirmation of the light microscopic findings that $M$. leprae can infect human Schwann cells in tissue culture. ${ }^{8}$ In a parallel study ${ }^{8}$ on the same culture, $71 \%$ of the Schwann cells contained one or more acid-f ast bacilli $48 \mathrm{hr}$ after infection. The ultrastructural findings closely resemble those found in the Schwann cells of nerves of leprosy patients and in those of armadillos infected with $M$. leprae. We did not, however, observe any bacteria lying free in Schwann cell cytoplasm as described by Job. ${ }^{1}$ Indeed, in our experiments the membranes surrounding the bacilli appeared unusually prominent and may possibly be a special feature of Schwann cells in tissue culture infected with $M$. leprae; an observation requiring further investigation.

Most of the $M$. leprae observed here were evenly stained, suggesting that they were still viable. Thus human Schwann cells in tissue culture do not appear to destroy viable M. leprae although other workers have claimed that such bacilli are destroyed within rat Schwann cells. ${ }^{10}$ The few fragmented bacilli may well have been dead before they were added to the cultures. Also, the ultrastructural appearance of the Schwann cells was not altered by the presence of M. leprae within them, suggesting that the bacteria were not unduly toxic. Moreover, the Schwann cell is responsible for making myelin in the peripheral nerve, yet ultrastructural studies have shown that the presence of $M$. leprae does not cause gross structural abnormalities in the myelin sheath. ${ }^{1}$

The experiments described here show that it is possible to reproduce the findings which occur in Schwann cells in nerves of leprosy patients. These techniques could therefore be used to study various aspects of the interaction between $M$. leprae and the Schwann cells.

\section{Acknowledgments}

We are most gratef ul to Dr J Colston, National Institute for Medical Research, London, for the gift of the armadillo-derived leprosy bacilli and Dr Wong, tissue bank, Royal Marsden Hospital, for supplying foetal tissues. We also thank $\mathbf{M r} \mathbf{J}$ Bowles for technical assistance.

\section{References}

1 Job CK. Mycobacterium leprae in nerve lesions in leprosy: an electron microscope study. Arch pathol, 1970; 89: 195-207.

2 Finlayson MH, Bilbao JM, Lough JO. The pathogenesis of the neuropathy in dimorphous leprosy: Electron microscopic and cytochemical studies. J Neuropath Exp Neurol, 1974; 33: 446-55.

3 Yoshizumi MO, Kirchheimer WF, Asbury AK. A light and electron microscopic study of peripheral nerves in an armadillo with disseminated leprosy. Int J Le pr, 1974; 42: 251-9.

4 Balentine JD, Chang SC, Issar SL. Inf ection of armadillos with M ycobacterium leprae; ultrastructural studies of peripheral nerve. Arch Path Lab Med, 1976; 100: 175-81.

5 Wood PM. Separation of functional Schwann cells and neurons from normal peripheral nerve tissue. Brain Res, 1976; 115: 361-75. 
${ }^{6}$ Brockes JP, Fields KL, Raff MC. Studies on cultured rat Schwann cells. I. Establishment of purified populations from cultures of peripheral nerve. Brain Res, 1979; 165: 105-18.

7 Askanas? ??

8 Samuel NM, Mirsky R, Grange JM, Jesson K. Induction of Ia antigens by gamma interferon on human Schwann cells infected with Mycobacterium leprae. Clin Exp Imm, 1987 (in press).

9 Bunge MB, Williams AK, Wood PM. Neuron-Schwann cell interaction in basal lamina formation. Dev Biol, 1982; 92: 449-60.

10 Band AH, Chitamber SD, Bhattacharya A, Talwar GP. Mechanism of phagocytosis of mycobacteria by Schwann cells and their comparison with macrophages. Int J Lepr, 1986; 54: 292-9.

11 Askanas V, Engel WK, Dalakas MC, Lawrence JV, Carter LS. Human Schwann cells in tissue culture. Histochemical and ultrastructural studies. Arch Neurol, 1980; 37: 329-37.

\section{NEWS AND NOTES}

\section{Meralgia paraesthetica (Bernhardt's syndrome)}

Dr Terence Ryan, Medical Adviser to St Francis Leprosy Guild, London, has drawn our attention to an interesting communication in a recent issue of the German dermatological journal Der Hautarzt. It is entitled 'Alopecia in Meralgia paraesthetica'; Krause, K-H et al., from the Neurologische Universitatsklinik, Heidelberg, West Germany; Der Hautarzt, 1987; 38: 474-6. Two patients are described with characteristic loss or impairment of sensation over a quite extensive area on the antero-lateral aspect of the thigh (on one side). The interesting (and apparently new) observation in this article is that both cases showed loss of hair growth in this area. This syndrome is due to nipping or damage to the lateral cutaneous nerve of the thigh and such cases have, on several occasions, been misdiagnosed as having leprosy. Clinicians may be interested to consult this paper in the original.

\section{Fifty-three interesting things to do in your lectures}

This amusing and stimulating book carries a more serious message. It is a highly readable paperback of 157 pages, written by Graham Gibbs, Sue and Trevor Habeshaw, published by Technical and Educational Services Ltd, 37 Ravenswood Road, Bristol BS6 6BW. Price £6.00. The main chapter headings are: structuring the process; improving student notes; using handouts; structuring and summarizing content; linking lectures; holding attention; active learning during lectures and checking on learning. This little book will do us all a lot of good and is well worth the money.

\section{WHO. Report on Educational Material for Patients}

This full title is 'Report of an informal working group on educational material for patients' DAP/85.10. This meeting held in New Delhi, October 1985 was convened by the WHO Action Programme on Essential Drugs. Essentially it deals with educating patients on the correct use of drugs, including those used in leprosy. It is important reading for all concerned with health education and patient motivation. Apply: Action Programme on Essential Drugs and Vaccines, WHO, 1211 Geneva 27, Switzerland. 